VARIABEL VOL. 1 NO. 2 (2018): 60-65

p-ISSN: 2593-302X dan e-ISSN: 2599-3038

This work is licensed under

a Creative Commons Attribution-NonCommercial 4.0 International License.

\title{
Analisis Kompetensi Strategis Matematis Siswa pada Sistem Persamaan Linier Tiga Variabel (SPLTV) Kelas X SMK Negeri 3 Singkawang
}

\author{
Junaidi Sigit ${ }^{1}$, Citra Utami ${ }^{2}$, Nindy Citroresmi Prihatiningtyas ${ }^{3}$ \\ STKIP Singkawang, Singkawang, Indonesia \\ sigitjunaidi.12@gmail.com ${ }^{1}$, citrautami1990@gmail.com ${ }^{2}$, nindy.citroresmi@gmail.com ${ }^{3}$
}

\section{Kata Kunci:}

Kompetensi Strategis

Matematis,

Sistem Persamaan Linier

Tiga Variabel

\begin{abstract}
ABSTRAK
Tujuan penelitian ini adalah untuk mendeskripsikan kemampuan, bentuk kesalahan, dan factor penyebab kompetensi strategis matematis siswa. Jenis penelitian yang digunakan adalah penelitian deskriptif kualitatif. Subjek dalam penelitian ini adalah siswa kelas X SMK Negeri 3 Singkawang dengan jumlah 30 siswa. Pengambilan data menggunakan instrumen berupa tes uraian yang disesuaikan dengan kemampuan kompetensi strategis matematis dan telah diuji menggunakan validasi isi, validasi konstruk, reliabilitas, daya pembeda, dan tingkat kesukaran. Teknik analisis data yang digunakan adalah penskoran, pedeskripsian data, dan wawancara. Hasil Penelitian menunjukan bahwa tingkat kemampuan strategis matematis siswa kelas X SMK Negeri 3 Singkawang pada materi Sistem persamaan linier tiga variabel secara keseluruhan berada pada kategori sedang dengan ratarata persentase nilai sebesar 52,84\%. Bentuk kesalahan siswa dalam menyelesaikan soal sistem persamaan linier tiga variabel kelas X SMK Negeri 3 Singkawang yaitu kesalahan konsep (salah memahami dan menerjemahkan soal dalam kalimat matematika), kesalahan prinsip (Salah dalam memilih rumus dan jawaban akhir), dan kesalahan operasi (salah melakukan operasi hitung). Faktor yang mempengaruhi kemampuan kompetensi strategis matematis siswa pada materi sistem persamaan linier tiga variabel kelas X SMK Negeri 3 Singkawang berasal dari faktor kognitif yaitu kesalahan konsep (tidak memahami perintah soal), kesalahan prinsip (tidak mampu mengembangkan ide), dan kesalahan operasi (ketelitian).
\end{abstract}

\section{PENDAHULUAN}

Matematika sebagai satu diantara ilmu dasar yang telah berkembang sangat pesat, baik dilihat dari materi maupun kegunaannya. Menurut Departemen Pendidikan Nasional (2006), untuk menguasai dan mengembangkan teknologi dimasa depan diperlukan penguasaan matematika sejak usia dini, hal ini disebabkan karena matematika membekali siswa dengan kemampuan berpikir logis, analitis, sistematis, kritis,dan kreatif, serta kemampuan bekerjasama. Dengan demikian setiap upaya pengajaran matematika sekolah haruslah selalu mempertimbangkan kecakapan matematis, 
VARIABEL Vol. 1 No. 2 (2018)

perkembangan matematika, penerapan dan penggunaan matematika untuk menyelesaikan permasalahan sehari-hari.

Kecakapan matematis sangat penting dalam diri seseorang. Menurut Kilpatrick (2001) ada lima kecakapan matematis yang harus dimiliki oleh siswa, agar dapat memecahkan masalah matematika dalam pembelajaran yaitu 1) pemahaman konseptual (conceptual understanding), 2) kelancaran procedural (procedural fluency), 3) kompetensi strategis (strategic competence), 4) penalaran adaptif (adaptif reasoning), 5) disposisi produktif (productive disposition). Satu diantara bagian penting dari kecakapan matematis yang harus dimiliki oleh siswa adalah kompetensi strategis. Karena menurut Kilpatrick (2001) berpendapat bahwa kompetensi strategis salah satu dari kecakapan matematis yang harus dikuasai oleh siswa dalam pembelajaran matematika. Menurut Spencer (2006:106) Kompetensi Strategis adalah suatu kemampuan untuk merumuskan, merepresentasikan, serta menyelesaikan soal permasalahan matematika. Sejalan dengan Syukriani (2016) kompetensi strategis merupakan keterampilan yang penting untuk ditumbuh kembangkan dalam diri siswa. Karena kompetensi strategis merupakan kemampuan untuk mengontrol prilaku strategis siswa dalam menyelesaikan masalah matematika. Lebih lanjut, pentingnya kompetensi strategis ditegaskan oleh Kilpatrick (2001) yaitu:

1) Mampu memahami masalah, yaitu siswa mampu menerjemahkan masalah kedalam unsur-unsur yang diketahui dan ditanyakan dari permasalahan.

2) Mampu memilih metode penyelesaian yang efektif dalam menyelesaikan suatu permasalahan.

3) Menemukan solusi dari suatu permasalahan. Tanpa kompetensi strategis matematis yang cukup, siswa akan mengalami kesulitan memperdalam pemahaman tentang ide-ide matematika atau memecahkan masalah matematika dalam pembelajaran.

Menurut Mursid (2014) salah satu kegiatan dalam belajar matematika adalah menyelesaikan soal matematika. Hal ini dikarenakan dalam penyelesaian soal matematis, siswa akan mendapat pengalaman menggunakan pengetahuan dan keterampilan yang sudah dimiliki untuk diterapkan dalam pemecahan masalah kompetensi strategis. Siswa membutuhkan pengalaman dan latihan dalam merumuskan masalah sebagaimana halnya dalam memecahkan masalah, mereka harus mengetahui berbagai macam strategi pemecahan masalah serta mengetahui strategi yang mana yang berguna dalam menyelesaikan suatu permasalahan. Ketika menghadapi suatu permasalahan, siswa harus mampu memformulasikan, memilih informasi-informasi yang relevan dengan masalah tersebut, serta mengetahui bagaimana cara dan strategi yang harus dipilih untuk diterapkan dalam memecahkan masalah tersebut. Dengan demikian Kompetensi strategis mutlak harus dimiliki dan dikembangkan oleh siswa dalam belajar matematika. Kompetensi strategis mempunyai peranan yang dominan dalam memecahkan masalah matematis.

Menurut Suherman (2013) bahwa masalah memuat situasi yang mendorong seseorang untuk ingin menyelesaikannya. Tetapi untuk dapat menyelesaikan masalah tersebut, masih membutuhkan waktu untuk memikirkan cara atau strategi untuk bisa menemukan penyelesaiannya. Menyelesaikan masalah harus melibatkan beberapa pengalaman dalam menyelesaikan berbagai masalah sebelumnya. Tidak dapat secara langsung mengetahui cara menyelesaikannya dengan benar.

Berdasarkan fakta keikutsertaan Indonesia berpartisipasi dalam PISA (Programme for International Student Assessment) tahun 2012 (Syukriani, 2016) Indonesia berada pada peringkat ke 64 dari 65 negara dengan skor yang diperoleh adalah 375. Peringkat pertama diperoleh Negara Cina dengan skor 613. Sejak tahun 2000 sampai tahun 2012, Indonesia selalu berada pada peringkat di atas 38 (PISA, 2013). Fakta tersebut menyimpulkan bahwa siswa Indonesia belum mengoptimalkan kompetensi strategisnya dalam menyelesaikan masalah kontekstual.

Dari hasil penelitian Nirawati (Gailea, 2013) menunjukkan bahwa siswa masih kesulitan untuk mengubah soal cerita dalam bentuk simbol matematis, dan ini menunjukan bahwa siswa tersebut merasa kesulitan dalam mempresentasikan suatu permasalahan yang terkait pada kompetensi strategis. Dari pernyataan tersebut dapat diketahui bahwa rendahnya kompetensi strategis siswa dalam menyelesaikan permasalahan matematika. 
VARIABEL Vol. 1 No. 2 (2018)

Page: $60-65$

Berdasarkan hasil wawancara yang telah dilakukan terhadap salah satu guru matematika SMK Negeri 3 Singkawang pada tanggal 8 November 2016, tentang hasil belajar siswa pada materi sistem persamaan linier tiga variabel diperoleh sebagai berikut; 1) nilai rata-rata ulangan harian siswa hanya 50 padahal Kriteria Ketuntasan Minimal (KKM) yaitu 65; 2) siswa yang tuntas belajar sekitar 30\% dari setiap kelasnya; 3) rendahnya hasil belajar siswa pada materi ini karena banyak siswa yang melakukan kesalahan dalam menyelesaikan soal. Hal ini menunjukkan bahwa kompetensi siswa rendah.

Sejalan dengan hal tersebut materi yang dipilih dalam penelitian ini adalah sistem persamaan linier tiga variabel khususnya pada submateri menyelesaikan masalah yang berkaitan dengan sistem persamaan linier tiga variabel. Pertimbangan peneliti memilih materi ini karena masih rendahnya hasil belajar siswa yang dapat dilihat dari hasil pra observasi dan wawancara kepada salah satu guru matematika. Banyaknya masalah-masalah dalam kehidupan sehari-hari yang dapat dipecahkan secara sederhana dalam bahasa simbol pada materi sistem persamaan linier tiga variabel sehingga penting untuk dipelajari, bahkan bukan hanya sekedar dipelajari namun juga harus dipahami.

Gambaran permasalahan tersebut menunjukkan bahwa begitu pentingnya kompetensi strategis dalam pembelajaran matematika, sehingga perlu diungkap lebih jauh mengenai kompetensi strategis matematis siswa pada materi sistem persamaan linier tiga variabel melalui suatu penelitian. Hal ini menyatakan bahwa pada upaya pembelajaran sangat penting bagi seorang pendidik untuk melaksanakan tahap awal pembelajaran. Tahap ini merupakan tahap seorang pendidik mengetahui dan memahami bekal awal yang dimiliki siswanya. Bekal awal yang termasuk ke dalam tahap tersebut yaitu mengetahui potensi siswa dalam belajar, khususnya terkait kompetensi strategisnya.

Berdasarkan uraian tersebut, dapat diduga bahwa kemampuan strategis matematis sangat mempengaruhi kemampuan siswa pada proses pembelajaran matematika khususnya pada materi sistem persamaan linier tiga variabel, sehingga perlu dilakukan penelitian tentang "Analisis Kompetensi Strategis Matematis Siswa Pada Materi Sistem Persamaan Linier Tiga Variabel Kelas X SMK Negeri 3 Singkawang”. Dengan mengetahui kompetensi strategis siswa, guru diharapkan dapat merancang strategi pembelajaran yang efektif untuk diterapkan dalam pembelajaran matematika agar siswa memiliki kompetensi strategis yang baik dan proses pembelajaran matematika dikelas X SMK Negeri 3 Singkawang dapat berlangsung secara optimal sehingga bisa tercapai tujuan yang diinginkan.

\section{METODE PENELITIAN}

Jenis penelitian yang digunakan dalam penelitian ini adalah kualitatif. Menurut Sugiyono (2015:15) metode penelitian kualitatif adalah pendekatan penelitian yang berlandaskan pada filsafat postpositivisme, digunakan untuk meneliti pada kondisi obyek yang alamiah dimana peneliti adalah kunci, teknik pengumpulan data dilakukan secara dokumentasi dan triangulasi (gabungan) analisis data bersifat kualitatif. Adapun sekolah yang menjadi tempat penelitian adalah SMK Negeri 3 Singkawang yang beralamat di Jln. Kridasana Kec. Singkawang Barat. Subjek yang digunakan dalam penelitian ini adalah siswa kelas X Boga 1 yang terdiri dari 30 siswa.

Teknik analisis data yang digunakan dalam penelitian ini adalah penelitian deskriptif dengan pendekatan kualitatif. Moloeong (2011:31) menyatakan penelitian deskriptif dirancang untuk mengumpulkan informasi dengan tujuan mendeskripsikan suatu gejala atau kejadian yang terjadi pada saat ini Dalam penelitian ini akan diperoleh data kulitatif sehingga untuk menganalisis data didapatkan dari pemberian tes tertulis dan wawancara.

\section{HASIL DAN PEMBAHASAN}

\section{Kemampuan Kompetensi Strategis Matematis Siswa}

Berdasarkan hasil tes kemampuan kompetensi strategis matematis yang dikerjakan oleh siswa, diperoleh data hasil persentase nilai rata-rata siswa dan telah dikelompokan berdasarkan lima kategori kemampuan yang disajikan pada Gambar 1. 


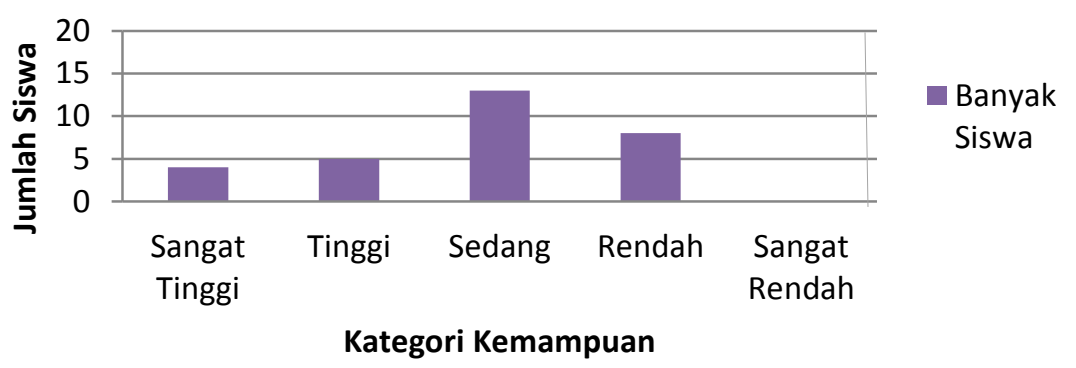

\section{Gambar 1. Diagram Rekapitulasi Nilai Tes Kemampuan Kompetensi Strategis Matematis Siswa}

Berdasarkan Gambar 1, diagram rekapitulasi nilai tes kemampuan Kompetensi Strategis Matematis siswa kelas X boga 1 SMK Negeri 3 Singkawang diperoleh diantara 30 siswa yaitu; 4 siswa berada pada kategori sangat tinggi, 5 siswa berada pada kategori tinggi, 13 siswa berada pada kategori sedang, 8 siswa berada pada kategori rendah, dan tidak ada siswa yang berada pada kategori sangat rendah. Secara keseluruhan rata-rata persentase nilai berada pada kategori sedang dengan persentase sebesar $52,84 \%$.

Hal ini sejalan dengan teori belajar kontrukstivistik (Rangkuti, 2014:6) menyatakan bahwa pengetahuan seseorang itu dibangun oleh seseorang itu sendiri untuk memberikan keaktifan terhadap manusia untuk belajar menemukan sendiri kompetensi, strategis, dan pengetahuan dan hal lain guna mengembangkan dirinya sendiri. Kemudian dari hasil tes kemampuan kompetensi strategis matematis siswa dapat diketahui nilai rata-rata persentase kelompok atas, tengah, dan bawah pada setiap indikator yang disajikan pada Gambar 2.

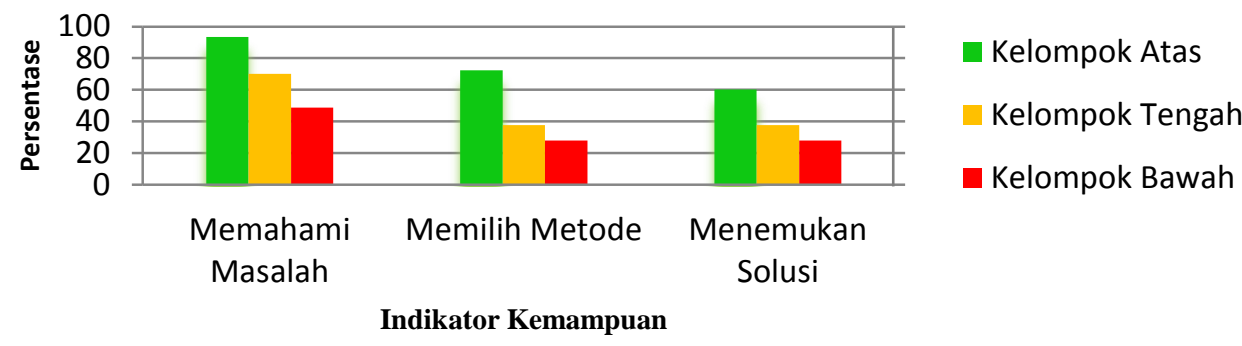

\section{Gambar 2. Diagram Rekapitulasi Nilai Tes Per-Indikator Kemampuan Kompetensi Strategis Matematis Siswa}

Berdasarkan Gambar 2, dapat dideskripsikan hasil yang diperoleh pada setiap indikator secara keseluruhan siswa yaitu; untuk indikator memahami masalah memperoleh rata-rata persentase skor sebesar 70,74 \% dengan kategori tinggi. Hal ini sesuai dengan pendapat Syukriani (2016:6) menggunakan strategi dalam memahami, memfomulasi dan mereoresentasi situasi masalah sangat dipengaruhi oleh pengalaman belajar siswa.

Untuk indikator memilih metode memperoleh rata-rata persentase skor sebesar 45,93\% dengan kategori sedang. Hal ini sesuai dengan pendapat dari Kilpatrick (Syukriani, 2016:7) bahwa untuk dapat mempresentasikan situasi masalah secara benar maka perlu memahami situasi dari suatu masalah. Pada indikator menemukan solusi memperoleh rata-rata persentase skor sebesar 41,85\% dengan kategori sedang. Hal ini sesuai dengan pendapat Mursid (2014:24) penyelesaian soal matematika adalah suatu proses pencarian jawaban (solusi) atas soal matematika yang diberikan dengan menggunakan pengetahuan yang ada. 


\section{VARIABEL Vol. 1 No. 2 (2018)}

\section{Bentuk Kesalahan Kemampuan Kompetensi Strategis Matematis Siswa}

Bentuk kesalahan siswa dalam menyelesaikan soal kompetensi strategis matematis siswa di kelas $\mathrm{X}$ boga 1 SMK Negeri 3 Singkawang. Berdasarkan analisis terhadap jawaban siswa dari keenam subjek terpilih dapat disimpulkan sebagai berikut.

a. Kesalahan konsep, yaitu kesalahan siswa dalam menafsirkan dan menggunakan konsep matematika, seperti: Salah dalam memahami makna soal dan menerjemahkan soal kedalam kalimat matematika

b. Kesalahan prinsip, yaitu kesalahan siswa dalam menafsirkan dan menggunakan rumus-rumus matematika, seperti: Salah dalam memilih rumus matematika dan jawaban akhir soal.

c. Kesalahan operasi, yaitu kesalahan siswa dalam menggunakan operasi dalam matematika baik penjumlahan, pengurangan, pembagian, maupun perkalian.

Hal ini sesuai dengan bentuk kesalahan yang dikemukakan oleh Soedjadi (2000) bahwa beberapa kesalahan yang dilakukan siswa, yaitu kesalahan konsep (yaitu kesalahan siswa siswa dalam menafsirkan, menggunakan konsep matematika seperti salah dalam memahami makna soal dan salah dalam mnerjemahkan soal kedalam bentuk model matematika. Kesalahan prinsip (yaitu kesalahan siswa dalam menafsirkan, menggunakan rumus-rumus matematika seperti salah menggunakan aturanaturan yang ada pada rumus matematika dan salah dalam penarika kesimpulan dalam menetukan jawaban akhir soal. Kesalahan operasi yaitu kesalahan siswa dalam menggunakan operasi dalam matematika baik penjumlahan, pengurangan, pembagian, maupun perkalian.

Faktor Penyebab Kesalahan Siswa Dalam Menyelesaikan Soal Kompetensi Strategis Matematis Faktor penyebab kesalahan siswa dalam menyelesaikan soal kompetensi strategis matematis siswa di kelas X boga 1 SMK Negeri 3 Singkawang. Berdasarkan analisis terhadap jawaban siswa dari keenam subjek terpilih dapat disimpulkan sebagai berikut:

a. Kesalahan konsep, yaitu tidak memahami soal dengan baik.

b. Kesalahan prinsip, yaitu tidak mampu mengebangkan ide dalam menyelesaikan soal kemampuan.

c. Kesalahan operasi, yaitu kurang ketelitian melakukan perhitungan dalam menyelesaikan soal kemampuan.

Hal ini sesuai dengan pendapat Soleh (1998) mengemukakan bahwa faktor yang mempengaruhi kesulitan belajar siswa secara umum dapat dibedakan yaitu kesulitan yang disebabkan oleh faktor kognitif mencakup kemampuan intelektual siswa dan cara siswa mencerna materi matematika dalam pikirannya.

\section{KESIMPULAN}

Tingkat kemampuan strategis matematis siswa kelas X SMK Negeri 3 Singkawang pada sistem persamaan linier tiga variabel secara keseluruhan berada pada kategori sedang dengan rata-rata persentase nilai sebesar 52,84\%. Adapun tingkat pada setiap indikator kemampuan number sense sebagai berikut: a) pada indikator pertama yaitu memahami situasi serta kondisi dari suatu permasalahan siswa berada pada kategori tinggi dengan rata-rata persentase skor sebesar $70,74 \%, \mathrm{~b}$ ) pada indikator kedua yaitu memilih dan mengembangkan metode yang efektif siswa berada pada kategori sedang dengan rata-rata persentase skor sebesar $45,93 \%$, c) pada indikator ketiga siswa berada pada kategori sedang dengan nilai rata-rata persentase skor sebesar $41,85 \%$. Bentuk kesalahan siswa dalam menyelesaikan soal sistem persamaan linier tiga variabel kelas X Boga 1 SMK Negeri 3 Singkawang yaitu kesalahan konsep (salah memahami dan menerjemahkan soal kedalam kalimat matematika), kesalahan prinsip (Salah dalam memilih rumus dan jawaban akhir), dan kesalahan operasi (salah melakukan operasi hitung). Faktor yang mempengaruhi kemampuan kompetensi strategis matematis siswa pada materi system persamaan linier tiga variabel kelas X SMK Negeri 3 Singkawang berasal dari faktor kognitif yaitu kesalahan konsep (tidak memahami perintah soal), kesalahan prinsip (tidak mampu mengembangkan ide), dan kesalahan operasi (ketelitian). 


\section{VARIABEL $O$ Vol. 1 No. 2 (2018)
Page: $60-65$ \\ UCAPAN TERIMA KASIH}

Penulis mengucapkan terima kasih kepada Drs. Andi Mursidi, M.Si. selaku ketua STKIP Singkawang yang telah memberikan arahan dan bimbingan selama mengikuti perkuliahan di STKIP Singkawang, kepada bapak Muntuh, S.Pd. selaku kepala SMKN 1 Monterado yang telah memberikan izin untuk melakukan uji coba soal, dan kepada Bapak Gunanto, S.H. yang telah memberikan izin untuk melakukan penelitian.

\section{DAFTAR PUSTAKA}

Depdiknas. (2006). Kurikulum Tingkat Satuan Pendidikan. Jakarta: Depdiknas.

Gailea, N. P. (2013). Peningkatan Kemampuan Kompetensi Strategis serta Kemandirian Belajar Siswa melalui Pendekatan SAVI. Skripsi. Bandung: UPI. Tidak Dipublikasikan.

Kilpatrick, S. \& Findell. (2001). Adding It Up: Helping Children Learn Mathematics. Washington, DC: National Academy Press.

Moleong, L. J. (2011). Metodologi Penelitian Kualitatif. Bandung: Remaja Rosdakarya.

Mursid. (2014). Analisis Strategic Competence (Kompetensi Strategis) Siswa Tipe Melankolis dalam Menyelesaikan Soal Matematika pada Materi Sistem Persamaan Linier Dua Variabel (SPLDV) Kelas VIII SMP Jambi. Skripsi. Jambi: FKIP Universitas Jambi. Tidak Dipublikasikan.

PISA. (2013). Result and Framework. http://en.wikipedia.org. (Diakses tanggal 27 Febuari 2017).

Rangkuti, A. N. (2014). Konstruktivisme dan Pembelajaran Matematika. Jurnal Darul Ilmi, 2(2), 6176.

Soedjadi. (2000). Kiat Pendidikan Matematika Indonesia. Jakarta: Depdiknas.

Soleh, M. (1998). Pokok-Pokok Pengajaran Matematika Sekolah. Jakarta: Depdikbud.

Spencer, M. Lyle \& Spencer, M. Signe. (2006). Competence at Work Revisi Edition: Model for Superior. New York: Wiley.

Sugiyono. (2015). Metode Penelitian Pendidikan. Bandung: Alfabeta.

Suherman. (2013). Strategi Pembelajaran Matematika Kontemporer. Bandung: UPI.

Syukriani. A. (2016). Kompetensi Strategis Siswa SMA Berkemampuan Tinggi dalam Menyelesaikan Masalah Matematika. Prosiding Seminar Nasional, 2(1), 83-91. 